Article

\title{
Creative Enough to Become an Entrepreneur: A Multi-Wave Study of Creative Personality, Education, Entrepreneurial Identity, and Innovation
}

\author{
Jinyi Zhou ${ }^{1}$, Xingzi $\mathrm{Xu}^{2}$, Yawen $\mathrm{Li}^{3, *}$ and Chengcheng Liu ${ }^{2}$ \\ 1 Department of Business Administration, Donlinks School of Economics and Management, \\ University of Science and Technology Beijing, Beijing 100083, China; jinyi@ustb.edu.cn \\ 2 Department of Innovation, Entrepreneurship and Strategy, School of Economics and Management, \\ Tsinghua University, Beijing 100084, China; xuxz.16@sem.tsinghua.edu.cn (X.X.); \\ liuchch.15@sem.tsinghua.edu.cn (C.L.) \\ 3 Department of Management Science and Engineering, School of Economics and Management, \\ Beijing University of Posts and Telecommunications, Beijing 100876, China \\ * Correspondence: warmly0716@bupt.edu.cn
}

Received: 7 April 2020; Accepted: 12 May 2020; Published: 14 May 2020

\begin{abstract}
In order to sustain an innovative working style, entrepreneurs need to build unique identities. However, relatively few studies have investigated what types of individuals are more likely to construct an entrepreneurial identity. In the current study, drawing upon identity construction theory, we proposed that an important individual difference, creative personality, would have a positive impact on the construction of an entrepreneurial identity, which in turn would facilitate individuals' work-related innovations. Education was proposed to moderate this mediating effect, in that individuals with a higher level of education would have a higher possibility of constructing an entrepreneurial identity and producing sustainable innovations. We suggested that with considerable education, creative individuals would become entrepreneurs during their career progression and harvest more work-related innovations. A multi-wave sample of 12,686 participants from the National Longitudinal Survey of Youth (1979) was used to test our hypotheses. The results indicated that creative personality, along with education, interactively predicted an individual's entrepreneurial identity, which in turn predicted innovation. Education significantly moderated the mediating effect of entrepreneurial identity. The theoretical and practical implications were also discussed.
\end{abstract}

Keywords: creative personality; entrepreneurial identity; identity construction; education; innovation

\section{Introduction}

Entrepreneurs need to construct a unique and distinctive identity [1-3]. Entrepreneurial identity has been defined as the constellation of claims around entrepreneurship that address "who entrepreneurs are" and "what entrepreneurs do" [4]. With a stable identity, entrepreneurs could follow the behavioral patterns underlying such an identity and thus have a sustainable and innovative working style. Researchers have addressed different characteristics or psychological traits associated with entrepreneurs that were different from those of salaried employees [5]. For example, prior studies indicated that entrepreneurs were different from salaried employees in terms of job autonomy, internal control, role ambiguity, and psychological well-being [6,7]. Generally, entrepreneurs were more creative than others [8] and could tolerate greater ambiguities $[9,10]$. They were more able than salaried employees to balance their work and life [11,12]. In addition, research linked genetic factors to entrepreneurship to demonstrate that some individuals were "born" to be entrepreneurs [12]. Although these differences may be established by entrepreneurs to achieve competitive advantages, 
social identity theory has also suggested that the unique identity that differentiates entrepreneurs from others would enhance the distinction $[4,13]$. This may then increase entrepreneurs' self-concepts of being more productive [14]. Being different was an individual basic need and the distinctiveness was beneficial to their psychological well-being to a certain extent [15]. In addition, an entrepreneurial identity existed apart from material products and service systems [16], which legitimized entrepreneurs' distinctiveness to influence judgments and assessments of investors [14].

Relatively few studies have investigated how to construct an entrepreneurial identity. Researchers have demonstrated that professional identity construction work was a communicative and mental process. Individuals could make sense of their own work and create a coherent yet distinct self through this process $[17,18]$. One's own understanding of who one wanted to be, as well as the socially accepted standards of who should do what, interactively influenced the construction of individuals' professional identities. Entrepreneurial experiences and activities [19], region-based discourses [20], the repertoire of narrative resources [21], and entrepreneurship education [22] have been found to be influencing factors on the emergence of entrepreneurial identity. Environmental and individual factors tended to influence entrepreneurial identity construction simultaneously [17]. Dispositional factors, such as personality, should be considered to determine who individuals wanted to be. For example, some researchers found that a creative personality could help individuals start their business through recognizing more opportunities [23] and others found that this personality could help individuals organize and process information better, which increased their tendency to be an entrepreneur [24].

Recently, researchers have called for more studies integrating creativity, innovation, and entrepreneurship [25]. The centrality of these three areas highlighted the importance of new ideas. Creativity was defined as identifying novel and useful ideas [26] and was a precursor of innovation, which was generally defined as the implementation of creative ideas [27,28]. Entrepreneurship was also a specific form of innovation that was related to the application of creativity and innovation to business ventures [29]. Traditional theories have provided numerous explanations about how creative ideas were transmitted to innovation, such as through knowledge sharing processes. Our study provided another approach, exploring whether individuals with a propensity to be creative can implement work-related innovations through entrepreneurship.

In the current study, we studied two main questions. One was how individual-environmental interactions influence an entrepreneurial identity, and the other was whether such an identity leads to positive outcomes. Creative personality is an important trait that encourages individuals to behave in a creative manner. Thus, it should be investigated whether individuals with a creative personality construct an entrepreneurial identity to customize their preferred work. We also emphasized the moderating role of individual education, which provided individuals with the necessary human capital to treat entrepreneurship as their professional identity. In addition, individuals follow their salient identity to engage in different behaviors [30]. As entrepreneurs were assumed to innovate, the current study also tested whether having an entrepreneurial identity could enable individuals to produce more innovations than salaried employees.

\section{Theoretical Framework and Hypotheses}

Identity construction theory indicated that identity work is an active process through which individuals construct their professional identity in different contexts $[23,24,31]$. This theoretical perspective views individuals as human agents that can actively customize their professional identity according to their preferred work content, as well as the social standards received from society $[23,24]$. Although prior studies have articulated that discourses or narratives may contribute to the construction of an entrepreneurial identity [20,22], more comprehensive studies on both individual and environmental factors were also helpful to improve our understanding of entrepreneurial identity construction. Thus, the current study investigated how personality and education interactively facilitated entrepreneurial identity construction, which facilitated individuals' work-related innovations. 


\subsection{Creative Personality and Entrepreneurial Identity}

Creative personality was defined as an individual trait from which individuals would behave in a creative manner across different conditions, and this dispositional factor will influence individuals' information processing and behavioral patterns in different social contexts [32].

A creative personality can influence individuals' behavioral patterns. For example, researchers articulated that creative individuals tended to assimilate information from diverse sources and were willing to employ novel and useful procedures [33]. Individuals with a creative personality had much more broad cognitive categorizations within their minds [32]. Creative individuals were more confident and tolerant of ambiguities when creating and implementing new ideas than others [32,34]. Other studies have unveiled the relationship between creative personality and entrepreneurship and the potential theoretical mechanisms [7]. For example, researchers found that being creative was critical in identifying opportunities [35], which was especially important for starting new businesses [36]. This kind of personality created broadened cognitive patterns that allowed for the high flexibility to process and connect unrelated familiar information, which was essential for entrepreneurship.

Identity is an individual's unique knowledge system that designates their motives, values, and social references [37]. This fluid self-system stems from previous experiences, reinforced by the environment, and is generally influenced by individuals' personalities [38]. The social-cognitive perspective of identity suggested that the temporal salience of identity is activated by both chronic and situational factors [39]. For example, Markus et al. [37] suggested that schemata (i.e., cognitive structures) should be built up from the cognitive representations of past experiences, and the formation of this cognitive structure was significantly influenced by individual differences. Moreover, a salient identity would direct the individuals' behavior. Brewer et al. [30] articulated that different levels of identity would have various social motives. Johnson et al. [40] found that identity influenced an employee's behavior through a heuristic process (i.e., at the subconscious level).

Developmental psychologists proposed that individuals would go through consecutive stages of identity formation and that their identities would be influenced by several prior developmental stages [41]. Individuals' career transitions would keep accumulating and constructing their new professional identities [42]. Socialization literature emphasized the role of organizations in breaking newcomers' old identities and shaping their new identities by providing them with different meanings of their new jobs [43].

However, some studies directly examined the process through which individuals actively constructed their identities within specific social contexts [23,31]. For instance, Ibarra [23] proposed that professional identity can be constructed in social interaction, and individuals needed to try out possible selves to determine their desired end states. Pratt et al. [24] developed a whole identity construction theory by depicting the process through which individuals integrated their identities toward what they were doing. According to this theory, individuals need to prevent their work-identity integrity from being destroyed by customizing their identity to their preferred work content. They can use different customization types, such as enriching, patching, and splinting, to proactively maintain their identity-work consistency.

Entrepreneurs also construct unique identities [2] to fulfill their need for distinctiveness [44], which influences not only their businesses' success [4] but also their personal well-being and physical health [45]. Until recently, scholars attached importance to entrepreneur identities, but most of them focused on how the entrepreneur identity influenced individual business ventures [4]. Entrepreneurs were different from salaried employees in terms of creativity, information, and motivation. Entrepreneurship itself was defined as "behaviors that include demonstrating initiative and creative thinking, organizing social and economic mechanisms to turn resources and situations into practical accounts and accepting risk and failure" [46].

To be an entrepreneur, individuals needed to fulfill different roles simultaneously [47] and to tolerate the ambiguities from inside and outside the organization [9]. Based on identity construction theory, to successfully construct an entrepreneurial identity, individuals also needed to create, test, 
and integrate possible provisional selves [23] before they decided whether to enter entrepreneurship or not. Individuals needed to actively make use of the information that is relevant to their new entrepreneurial identity, such as performance feedback, to actively give meanings to (i.e., enrich) their new identities, to integrate business ventures they currently engage in with their "preferred selves," and to be customized to their professional identities as entrepreneurs [24].

Creative personality increases the possibility of constructing an entrepreneurial identity. Individual differences, such as personalities, would become one of the main influencing factors of individuals' preferred work content. Creative individuals tended to engage in more innovative businesses, and are more willing to take the risks of ambiguities. As indicated by identity construction theory, these kinds of individuals need to customize their identities according to their work content so as to maintain the identity-behavior integrity.

Maintaining entrepreneurial identity, individuals can easily engage in issues related to creativity, such as identifying opportunities and strategically claiming the legitimacy of their new ventures. Individuals will create or select and remain in roles that fit their personalities best. Prior studies linked personality to real entrepreneurship based on this theoretical line. For example, Zhao et al. [48] found that some types of personalities, such as extraversion, allowed individuals to run a business and helped them act effectively with relatively less conscious effort.

Following this perspective, in the current study, we suggested that creative personality, as an important individual difference variable, would increase the likelihood that individuals engage in more creative work content, while their professional identities can be integrated with their preferred work content through constructing an entrepreneurial identity. Therefore, individuals with creative personalities would be more likely to construct entrepreneurial identities, and our first hypothesis was as follows.

Hypothesis 1: Creative personality will have a positive relationship with entrepreneurial identity.

\subsection{The Moderating Role of Education}

General education is one of the most important forms of human capital that can be acquired from formal educational systems by individuals [49]. Human resource management literature has provided abundant theories regarding the effect of education [11,12]. For example, human capital theory [50] predicted that the efforts of individuals who possessed greater human capital, such as knowledge, skills, and experiences, would have a greater possibility of being rewarded by the market [51]. Prior studies revealed a relationship between education and career adaptability. Individuals with a higher education level had a greater likelihood of being promoted or successfully moving across different occupations.

The relationships between human capital and entrepreneurship outcomes have also been unveiled [52]. Researchers indicated that education improved entrepreneurial outcomes as it provided individuals with a better ability to understand the business environment, to assimilate more information, and to appropriately apply the application of technical knowledge to business functions [49]. Moreover, education represented a founder's professional imprint [53], which signaled to shareholders a high possibility of success and, therefore, was considered to be positively related to the likelihood of the new venture's survival.

Education facilitated the entrepreneurs' work integrity and identity. First, education helped individuals perceive that their businesses were more likely to survive. Individuals would choose a self-employed occupation only when it maximized their perceived benefits [54]. Individuals with a relatively high education would perceive greater possibilities of the success of their business ventures, thus improving their commitment toward their own business ventures. Therefore, individuals needed to customize their identities more to the work content they committed to [24].

Second, education ensured that individuals could explore different identities without fear of being left behind. Ibarra [23] articulated that adaptation to new roles depended on mechanisms that allowed 
individuals to experience many provisional selves and evaluate the results and alternative actions. In the era of boundaryless careers, education made it possible for individuals to easily transfer to new roles and identities. As the career opportunities transcended from a single organization, individuals needed to try different types of provisional selves to accommodate their preferred selves.

The opportunity to be self-employed would also be chosen by comparing with potential costs associated with giving up the benefits from alternative courses of action [36]. In addition, education helped individuals reduce their perceived costs of business failures because alternative opportunities, such as returning to traditional salaried jobs, were only available when individuals held enough human capital. This made individuals more likely to engage in business ventures and integrate their identities with those ventures. Thus, in the current study, we also emphasized that education, as an important human capital acquired from the environment, moderated the relationship between creative personality and entrepreneurial identity. The second hypothesis was as follows.

Hypothesis 2: Education will moderate the relationship between a creative personality and entrepreneurial identity. For individuals with a higher level of education, creative personality will have a more positive relationship with entrepreneurial identity than for individuals with a lower level of education.

\subsection{Outcome: Innovation}

Seminal studies indicated that different identities may lead to various social motives, social comparison systems, goals, and behavioral scripts $[30,55]$. The social cognitive perspective of identities suggested that even through chronic identities may stem from cultural backgrounds [45], the temporal salience of a specific identity depended on the current environment [37]. Activating one type of identity would urge individuals to behave accordingly [55]. Following the guides of activated identities reduced individuals' conscious efforts, while an inconsistency between identity and behavior would induce both cognitive and emotional dissonance [45]. Linking identity with individuals' actual behaviors can help them fully engage in such behaviors.

Entrepreneurial identity was derived from both the definition of the social group of being an entrepreneur [13] and individuals' own constructions and choices of their roles. A founder's identity not only profoundly shaped the entrepreneurs' key decisions but also significantly influenced their start-ups and other relevant stakeholders [56]. Generally, having a salient entrepreneurial identity indicated that individuals had the basic motives to engage in innovations that included risk-taking and ambiguities [57], as entrepreneurship itself was premised on the generation of new ideas, identifying potential opportunities [36], and creating possibilities [58]. Congruence between individuals' self-concepts and entrepreneurs' social identities would generate positive emotions, and a high entrepreneurial identity centrality fueled entrepreneurship passions.

Societal and role expectations of becoming an entrepreneur were to create and implement solutions to deal with uncertainties. Incorporating an entrepreneurial identity, individuals would like to create innovative and productive solutions to current problems. Although from an economic perspective, entrepreneurship might be an instrument for individuals to achieve financial success, more recent studies have revealed the innovative aspect of being an entrepreneur [59]. Therefore, the current study suggested that being an entrepreneur would facilitate individuals engaging in innovation. Entrepreneurial identity construction could also serve as an intermediate mechanism through which individuals transmitted their creative propensity to innovation. Thus, our third hypothesis was as follows.

Hypothesis 3: Entrepreneurial identity will have a positive relationship with innovation. 


\subsection{Complete Theoretical Model}

In the current study, based on the identity construction theory, we proposed a theoretical framework in which creative personality as an individual difference interacted with education that was acquired from the environment. The interaction between these two factors helped individuals construct an entrepreneurial identity, which consequently enhanced work-related innovations. A moderated mediation model was proposed. For individuals with higher education, the mediating effect of an entrepreneurial identity between creative personality and innovation will become more positive. Social cognitive theory [60] also provided us with some important insights that we highlighted in the human agency's cognitive schema (i.e., identity) as an outcome of environmental and individual interactions, and such an identity will, in turn, guide individuals' behaviors. Please see Figure 1 for the complete theoretical model. We proposed our fourth hypothesis as follows.

Hypothesis 4: Education will moderate the mediating effect of entrepreneurial identity on the relationship between creative personality and innovation. For individuals with higher education, such a mediating effect will become more positive.

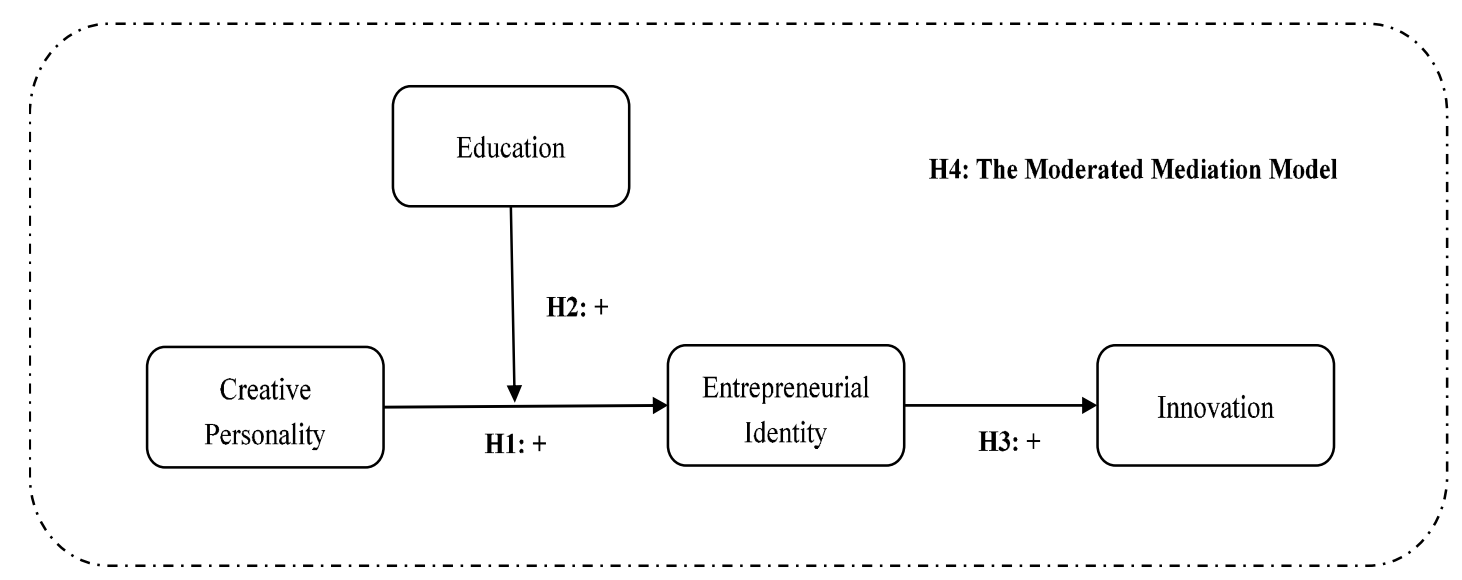

Figure 1. Complete theoretical model.

\section{Methods}

\subsection{Sample Descriptions}

The sample of the current study consisted of participants from the National Longitudinal Survey of Youth 1979 (NLSY 79), which was a longitudinal study with a representative sample all over the United States that started in 1979. This is a publicly accessible dataset; therefore, researchers easily obtained this data through the website of this project. The whole cohort of this study was interviewed annually from 1979 to 1994 and biennially after 1994 until 2016. We chose this project to test our hypotheses as this was a representative dataset that could cover all social classes in the United States. This significantly improved the robustness of the results considering that individuals with different socio-economic statuses are included. Moreover, this was a longitudinal dataset collected for more than 35 years, offering opportunities for researchers to track individuals' lifetime development. This dataset is also widely used in management, psychology, and the labor economic domain. Thus, it was appropriate for us to employ in this project.

A total of 12,686 participants with 6403 males (50.47\%) and 6283 females (49.53\%) covered participants from all social classes and familial backgrounds in America. Moreover, this study tracked American youth born between 1957 and 1964, and the average age of these participants in the first interview (1979) was 17.90 (SD = 2.31). All participants' career-related information was comprehensively collected, including demography, employment, entrepreneurship, familial 
background, and psychological variables, to provide us with a well-informed career-tracking dataset to investigate the participants' work experiences.

For the variables used in the current study, participants' creative personality and education were measured in 2014, and their entrepreneurial identity and innovation were cross-round variables, which combined all information gathered in 2010, 2012, 2014, and 2016. Participants' demographic variables, including age, gender, race, and their parents' education, were collected in 1979, while the poverty status was measured in 1980. Moreover, their marriage status was measured throughout all rounds between 1979 and 2016.

\subsection{Measures}

Creative personality: Participants' creative personalities were measured by an item selected from a personality scale (i.e., Ten-item Personality Inventory; TIPI) developed by Gosling et al. [61]. The TIPI is a brief measure of personalities that include extraversion, openness to experiences, agreeableness, and so on. This scale is widely used and can save participants time when completing a relatively long questionnaire. Creative personality was measured by one item out of two items measuring the openness to new experiences dimension because creativity is actually one dimension of openness to experiences. All participants were given a pair of personality traits first, and then they were asked to indicate how well the pair of traits, i.e., "conventional, uncreative", applied to them. A seven-point Likert scale was used with "1" meaning "disagree strongly" and "7" meaning "agree strongly". Reversed scoring of this item was used.

Education: Education was measured by the levels of education achieved by participants in 2014. At the time we collected this variable (2014), the average age of all participants was nearly 53 years old. According to the data, most participants completed their formal education before 1990. Participants' education took 21 values ranging from 0 (no education) to 20 (post-baccalaureate graduate). In our sample, more than $95 \%$ of participants had enrolled in a high school, and more than $85 \%$ had completed their high school education. Approximately $26 \%$ of all participants had a three-year college education, and more than $20 \%$ had completed a four-year college education. Approximately $10 \%$ of the participants had completed a graduate education. The participants' average educational level was nearly 13 years $(\mathrm{M}=13.24, \mathrm{SD}=2.63)$.

Entrepreneurial identity: Following prior studies that measured other types of identity [62], a trait-based measure was appropriate for us to indicate participants' entrepreneurial identity. Reviewers first explained to the participants that an entrepreneur is someone who has launched a business enterprise, usually with considerable initiative and risk, and then asked participants "whether you considered yourself to be an entrepreneur". This measure accorded with a rigorous definition of entrepreneurship, which not only needed to start or own a business but also had initiatives and could tolerate risks. Two choices were provided with " 1 " indicating "yes" and " 0 " indicating "no".

Although individuals who had ever owned a business may have a higher possibility of having an entrepreneurial identity than those without, from the current sample, we found that entrepreneurship and an entrepreneurial identity were actually different. First, the correlation between entrepreneurship and an entrepreneurial identity was only moderately significant (correlations $=0.37$ ). Second, for individuals who had an entrepreneurial identity $(\mathrm{N}=1525)$, only $42 \%$ of them had businesses $(\mathrm{N}=632)$. For those who had ever owned businesses $(\mathrm{N}=1194)$, only $54 \%$ had an entrepreneurial identity $(\mathrm{N}=632)$. Therefore, an entrepreneurial identity was a different construct from entrepreneurship, and our measure of entrepreneurial identity was appropriate.

Innovation: Entrepreneurs' work-related innovation was measured by the patent applications derived from their jobs. Using patent applications to measure individuals' innovation was adapted from prior studies [63]. Although this is not a perfect measure of innovation, we suggest patent applications can still measure the perception of individuals about the creative elements of their work. One item was used to ask participants "whether the work you significantly contributed had generated a U.S. patent application". Two choices were provided with " 1 " indicating "yes" and " 0 " indicating "no". 
Control variables: To rule out potential influences of other relevant variables, several control variables were included in our analyses. We controlled demographic factors such as age, gender, and race because they can influence individuals' entrepreneurship and also innovation. We also controlled for socioeconomic factors such as their parents' education, poverty status, and marital status to avoid their impacts on entrepreneurship or innovation.

Age was measured by the years after they were born and the gender was measured by creating a dummy variable whereas 0 represented male and 1 represented female.

Race was measured to indicate whether participants belonged to "Hispanic", "Black", or "non-Black and non-Hispanic" races. Two dummy variables were created to indicate the race that participants belonged to. Race 1 was designated to 1 when a participant belonged to the "Hispanic" group while Race 2 equaled 1 when the participant belonged to the "Black" group.

Parents' educations were measured by exactly the same scale measuring the education of participants. Twenty-one values ranging from 0 (no education) to 20 (post-baccalaureate graduate) were used to measure participants' mothers' and fathers' levels of education in 1979, as well.

Participants' poverty statuses were measured by using the familial poverty income guidelines of the U.S. Department of Health and Human Services from 1980.

The marital status variable was measured by asking participants to indicate the time of their first marriage. Of the 12,686 participants, 2578 (20.32\%) had never been married as of 2016. A dummy variable, marital status, was created to indicate whether participants had married before. The analytical results did not change when these control variables were removed.

\subsection{Analytical Strategy and Results}

The means, standard deviations, and correlations are shown in Table 1. The correlations between each pair of main variables were relatively low. Following prior entrepreneurship studies, we employed logistic regression to test our hypotheses [64] as both entrepreneurial identity and innovation were dichotomous variables. Hierarchical regression analyses were used with different variables entered into the regression model. We also investigated the collinearity statistics of the models, and all of the variance inflation factors (VIFs) for all the variables were less than 2.1 and were below the recommended value (i.e., 10) as suggested by Chatterjee and Price [65].

To test Hypothesis 1, we first entered creative personality and education into the regression model. From Model 2 in Table 2, the individuals with creative personality may have a higher possibility of having an entrepreneurial identity $(\beta=0.09, p<0.001)$. Therefore, Hypothesis 2 was supported. Regarding Hypothesis 2 , from Model 3, the interaction between creative personality and education was significantly related to entrepreneurial identity $(\beta=0.02, p<0.01)$. This result indicated that education indeed positively moderated the relationship between creative personality and entrepreneurial identity. 
Table 1. Correlations, means, and standard deviations.

\begin{tabular}{|c|c|c|c|c|c|c|c|c|c|c|c|c|c|c|}
\hline Variables & Mean & SD & $\mathbf{N}$ & 1 & 2 & 3 & 4 & 5 & 6 & 7 & 8 & 9 & 10 & 11 \\
\hline 1. Age & 17.90 & 2.31 & 12,686 & & & & & & & & & & & \\
\hline 2. Gender & 0.50 & 0.50 & 12,686 & 0.01 & & & & & & & & & & \\
\hline 3. Race 1 & 0.16 & 0.36 & 12,686 & $-0.05 * * *$ & 0.00 & & & & & & & & & \\
\hline 4. Race 2 & 0.25 & 0.43 & 12,686 & $-0.04 * * *$ & 0.00 & $-0.25 * * *$ & & & & & & & & \\
\hline 5. Mother Education & 10.87 & 3.17 & 11,878 & $0.04^{* * *}$ & $-0.02 *$ & $-0.40 * * *$ & -0.01 & & & & & & & \\
\hline 6. Father Education & 10.95 & 3.93 & 10,880 & $0.03 * *$ & -0.01 & $-0.29 * * *$ & $-0.09 * * *$ & $0.65 * * *$ & & & & & & \\
\hline 7. Poverty Status & 0.19 & 0.40 & 9891 & $-0.09 * * *$ & $0.05^{* * *}$ & $0.05^{* * *}$ & $0.21^{* * *}$ & $-0.23^{* * *}$ & $-0.21^{* * *}$ & & & & & \\
\hline 8. Marital Status & 0.80 & 0.40 & 12,686 & 0.03 ** & $0.10 * * *$ & $0.03^{* * *}$ & $-0.15^{* * *}$ & 0.01 & 0.00 & $-0.08^{* * *}$ & & & & \\
\hline 9. Creative Personality & 4.68 & 1.93 & 6943 & -0.01 & -0.02 & $-0.04 * * *$ & 0.00 & $0.08^{* * *}$ & $0.06^{* * *}$ & -0.02 & 0.02 & & & \\
\hline 10. Education & 13.24 & 2.63 & 7057 & 0.00 & $0.06 * * *$ & -0.16 *** & $-0.08^{* * *}$ & $0.40 * * *$ & $0.41^{* * *}$ & $-0.18^{* * *}$ & $0.08^{* * *}$ & $0.09^{* * *}$ & & \\
\hline 11. Entrepreneurial Identity & 0.19 & 0.39 & 7891 & 0.00 & $-0.15 * * *$ & $-0.05^{* * *}$ & $0.08^{* * *}$ & $0.05^{* * * *}$ & $0.05^{* * *}$ & 0.02 & $0.03 *$ & $0.06^{* * *}$ & $0.05^{* * *}$ & \\
\hline 12. Innovation & 0.01 & 0.11 & 7988 & 0.01 & $-0.05 * * *$ & $-0.03 * *$ & $-0.03 *$ & $0.07 * * *$ & $0.06^{* * *}$ & -0.02 & $0.04 * *$ & $0.03 *$ & $0.09^{* * *}$ & $0.08^{* * *}$ \\
\hline
\end{tabular}


Table 2. Logistic regression results: Creative personality, education, entrepreneurial identity, and innovation.

\begin{tabular}{|c|c|c|c|c|c|c|}
\hline \multirow{2}{*}{ Criteria } & \multicolumn{3}{|c|}{ Entrepreneur Identity } & \multicolumn{3}{|c|}{ Innovation } \\
\hline & Model 1 & Model 2 & Model 3 & Model 4 & Model 5 & Model 6 \\
\hline \multicolumn{7}{|l|}{ Control Variables } \\
\hline Age & $0.01(0.02)$ & $0.01(0.02)$ & $0.01(0.02)$ & $-0.02(0.05)$ & $-0.01(0.05)$ & $-0.01(0.06)$ \\
\hline Gender & $-0.80(0.07)^{* * * *}$ & $-0.79(0.08)^{* * *}$ & $-0.79(0.08)^{* * *}$ & $-1.21(0.27)^{* * *}$ & $-1.14(0.28) * * *$ & $-1.02(0.28)^{* * *}$ \\
\hline Race 1 & $0.02(0.11)$ & $0.05(0.12)$ & $0.04(0.12)$ & $-0.38(0.42)$ & $-0.41(0.46)$ & $0.40(0.46)$ \\
\hline Race 2 & $0.37(0.09)^{* * *}$ & $0.33(0.10)^{* *}$ & $0.33(0.10)^{* * *}$ & $-0.52(0.36)$ & $-0.47(0.36)$ & $-0.52(0.37)$ \\
\hline Mother Education & $0.03(0.02) *$ & $0.03(0.02)$ & $0.03(0.02)$ & $0.14(0.06)$ & $0.07(0.06)$ & $0.07(0.06)$ \\
\hline Father Education & $0.02(0.01)$ & $0.01(0.01)$ & $0.01(0.01)$ & $0.05(0.04)$ & $0.02(0.04)$ & $0.01(0.04)$ \\
\hline Poverty Status & $0.13(0.10)$ & $0.17(0.11)$ & $0.17(0.11)$ & $-0.38(0.48)$ & $-0.43(0.53)$ & $-0.45(0.53)$ \\
\hline Marital Status & $0.38(0.12)^{* * *}$ & $0.38(0.13)^{* *}$ & $0.38(0.13)^{* *}$ & $1.25(0.60)^{*}$ & $1.01(0.60)$ & $0.94(0.60)$ \\
\hline \multicolumn{7}{|l|}{ Predictors } \\
\hline Creative Personality & & $0.09(0.02)^{* * *}$ & $0.09(0.02) * * *$ & & $0.09(0.09)$ & $0.07(0.09)$ \\
\hline Education & & $0.03(0.02) *$ & $0.03(0.02)$ & & $0.21(0.05)^{* *}$ & $0.21(0.05)^{* * *}$ \\
\hline \multicolumn{7}{|l|}{ Interactions } \\
\hline Creative * Education & & & $0.02(0.01)^{* *}$ & & $0.00(0.01)$ & $-0.00(0.03)$ \\
\hline \multicolumn{7}{|l|}{ Mediator } \\
\hline Entrepreneurial Identity & & & & & & $0.76(0.27)^{* *}$ \\
\hline Pseudo $R^{2}$ & 0.03 & 0.04 & 0.04 & 0.08 & 0.10 & 0.11 \\
\hline
\end{tabular}

To test Hypothesis 3, we regressed innovation to entrepreneurial identity, and the relationship was also significant $(\beta=0.76, p<0.01)$. Therefore, having an entrepreneurial identity was significantly related to work-related innovation. Simple slope tests were used to depict the relationships between creative personalities and entrepreneurial identities, and the odds ratios of coefficients were used to represent the possibility of having an entrepreneurial identity. We found that when education was high, the relationship between creative personality and the possibility of an entrepreneurial identity was significantly positive ( $\beta=1.36, p<0.001)$; however, when education was low, such a relationship became insignificant ( $\beta=1.00, p=0.98$; please see Figure 2 for more details).

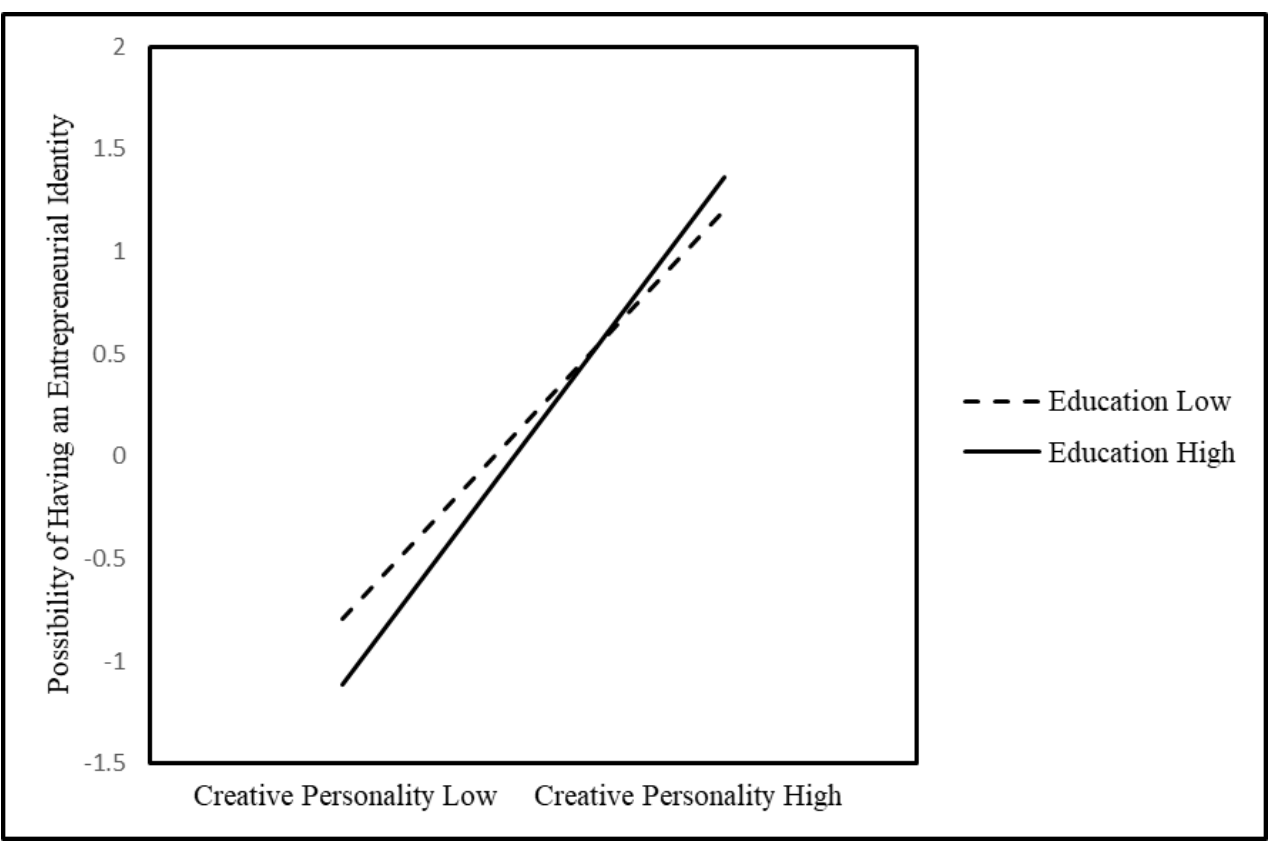

Figure 2. Moderating effect of education on the relationship between creative personality and the possibility of entrepreneurial identity. 
Regarding Hypothesis 4, a moderated mediation model was tested in M-plus 7.0 [66]. Considering that the outcomes of the theoretical model were dichotomous variables, a Monte Carlo simulation was used to test the indirect effect from creative personality to innovation through an entrepreneurial identity under different conditions (i.e., high or low education) by multiplying path "a" (i.e., from creative personality to an entrepreneurial identity) and path " $b$ " (i.e., from an entrepreneurial identity to innovation). From Table 3, when an individual's education was high, the indirect effect was significant (indirect effect $=0.12, \mathrm{SE}=0.05, \mathrm{Z}=2.47, p<0.05$ ). However, when education was low, such an indirect effect was not significant (indirect effect $=0.02, \mathrm{SE}=0.02, \mathrm{Z}=0.78, p=0.43$ ). Therefore, Hypothesis 4 was supported.

Table 3. Indirect effects of creative personality on innovation through entrepreneurial identity (Monte Carlo simulation).

\begin{tabular}{cccccccc}
\hline Predictor & Moderator & Mediator & Criterion & $\begin{array}{c}\text { Indirect } \\
\text { Effect }\end{array}$ & SE & Z & $\begin{array}{c}p \text { Value } \\
\text { (Two-Tailed) }\end{array}$ \\
\hline $\begin{array}{c}\text { Creative } \\
\text { Personality }\end{array}$ & Education Low (-1 SD) & Entrepreneurial & Innovation & 0.02 & 0.02 & 0.78 & 0.43 \\
\hline & Notentity ${ }^{*} p<0.05 . S E=$ standard error. & $0.12 *$ & 0.05 & 2.47 & 0.01 \\
\hline
\end{tabular}

\subsection{Additional Analyses}

Considering that the main variables used to test our hypotheses were collected from similar time periods, the concern of the common method bias should be carefully addressed. First, as individuals' creative personality was relatively stable across different career periods and this was associated with genes [67], the times we measured creative personality might not be a serious concern. Second, most participants completed their formal education before 1990, so this moderator was actually a state variable that happened long before the outcomes. Third, the methods we used to measure creative personality, education, entrepreneurial identity, and innovation were different, which can significantly reduce the common method bias. Fourth, following traditional remedies to reduce the concern of common method biases [68], several confirmative factor analyses (CFAs) were conducted.

We compared the fitness of a model with all continuous variables also loaded on one common method factor with that of the other model without such a factor. Log-likelihood ratio tests were used to compare the fitness of different models, and it turned out that the model with the common method factor significantly improved the fitness (model with factor: $-2 * \log$-likelihood $=71300.49$; model without factor: $-2 * \log$-likelihood $\left.=71361.75 ; \Delta \chi^{2}[3]=61.26, p<0.001\right)$. However, path analyses with a common method factor were tested in M-plus 7.0 [66], and the results were not significantly changed. Therefore, common method bias may not have been a serious concern in the current study.

\section{Discussion}

\subsection{Theoretical Contributions}

The theoretical contributions of this study were generally three-fold. Above all, although prior studies have indicated that individuals needed to experience several provisional selves to find their preferred professional identities, we aimed to contribute to identity construction theory $[23,31]$ by indicating that individuals with a stable trait, creative personality, would have a higher likelihood of constructing an entrepreneurial identity. However, the current literature has seldom considered individuals' traits as antecedents.

Many researchers found that certain types of individuals were "born" to be entrepreneurs $[11,48]$ and others even linked genes to entrepreneurship [67]. Stable individual differences should also be considered when predicting entrepreneurial identity. Therefore, the current study can link the entrepreneurship literature and individual difference literature by explaining that individuals with inherent creative manners would integrate their professional identities with entrepreneurship. As 
entrepreneurs are meant to be individuals who applied creative ideas to business ventures, maintaining an entrepreneurial identity would bring more benefits to creative individuals.

We attempted to introduce education as a boundary condition in our model. Education is crucial human capital that is positively related to the success of entrepreneurship. However, few prior studies investigated the relationship between education and entrepreneurial identity. In the current study, we suggested that considerable education was a necessary condition for individuals to forge an entrepreneurial identity, as education was actually a professional imprint that signaled whether current business ventures may ultimately survive or fail. Even if they fail, individuals can elegantly return to the traditional labor market. This guarantees that individuals could accept entrepreneurship as their career choice, thus facilitating identity-work integrity. Therefore, the current study linked the human capital literature [50] with the entrepreneurship literature by suggesting the important role of necessary human capital in entrepreneurial identity construction.

Last, in the current study, we managed to contribute to innovation by arguing that activating a salient entrepreneurial identity could facilitate sustainable innovation. Although prior studies articulated that an entrepreneurial identity could fuel individuals' entrepreneurship passions and generate positive emotions, researchers should not ignore one seemingly obvious consequence of entrepreneurship. Innovation was essential for entrepreneurs because the entrepreneurship process was the implementation of creative ideas for business ventures. As prior studies indicated, the activation of identity is a motivation-intensive process. Activating a professional identity urged individuals to fulfill the requirements of such an identity. In the current study, an entrepreneurial identity would, indeed, help individuals to reap more work-related innovations. Our study also linked the personality literature with the innovation literature [25]. Although these two areas of study seem distant, the focus of career choice and the longitudinal design could actually be used to help link them.

The complete theoretical model also followed the social cognitive perspective. From this perspective, an individual is a proactive agent that could cognitively assimilate information from the environment and then shape the following social motives. In the current study, adopting this individual-environment interaction perspective, we suggested that creative individuals with appropriate education should construct an entrepreneurial identity that prescribes their behavior patterns, such as creating more innovations.

We suggested that when investigating individuals' professional identities, apart from prior experience, such as narratives or discourses, researchers should also focus on relatively stable individual differences. In addition, researchers recently have called for a better understanding of the complex relationships among each pair of values from creativity, innovation, and entrepreneurship. In the current study, we suggested that creative individuals could easily implement their creative ideas by constructing an entrepreneurial identity. Therefore, the current study integrated personality, entrepreneurship, human capital, and innovation literature by proposing a complete theoretical model.

\subsection{Limitations}

The current study suffered from some limitations. First, although recommended remedies were employed, we still could not fully address the concern of the common method bias. Due to the limited information, we could not determine whether an entrepreneurial identity came before innovation.

Second, although we used entrepreneurial identity as the theoretical mechanism that mediated the relationship between creative personality and innovation, other potential mechanisms should also be investigated. For example, it might be possible that creative individuals can assimilate information from diverse sources, which can help individuals implement creative ideas. As the componential theory of creativity suggested, task-relevant, creativity-relevant, and intrinsic motivation were critical factors for creativity. Future studies should investigate whether intrinsic motivation can also mediate such a relationship.

Last, the sample we used was collected in the United States and thus may suffer from the limitation that the cultural background may have influenced the results $[45,69]$. It is possible that within an 
individualistic culture context that cherished individuals' efforts and encouraged entrepreneurship, creative personality might be a positive trait that increased innovation. However, within a collectivistic culture context, the relationship between creative personality and an entrepreneurial identity or innovation could be different. Future studies should carefully examine the influences of culture to infer a clear depiction of the entrepreneurial identity construction process.

\subsection{Future Directions}

Considering the limitations of this study, there are some recommendations for future studies. For example, future research can employ a more rigorous data-collecting strategy to infer the relationships among the main variables in our hypotheses. Experimental designs can also be used to determine the directions of each relationship and to conclude the causalities within our theoretical model. More rigorous measures of the main variables, such as creative personality and entrepreneurial identity, should be considered in the future. Other potential boundary conditions, such as environmental factors, should also be considered. Real entrepreneurship rather than only entrepreneurial identity should also be tested and a rigorous design that can ensure the time sequence should be conducted in order to obtain more robust results.

\subsection{Conclusion}

Identity is a crucial factor for a successful entrepreneur. In the current study, based on the identity construction theory, we found that creative individuals were more likely to construct an entrepreneurial identity, which contributed to their work-related innovations. Education moderated this mediating effect, and for individuals with a higher level of education, the mediating effect of an entrepreneurial identity became more significant. As entrepreneurial identities have received recent attention, we hope that the current research can stimulate more studies that can apply identity theories to entrepreneurship fields in the future.

Author Contributions: All authors were involved in preparing the manuscript. J.Z. contributed to the Conceptualization, Data curation, Formal analysis, Methodology, and Writing. X.X. contributed to the Data curation and Methodology. Y.L. contributed to the Conceptualization, Formal analysis, and Writing. C.L. contributed to the Methodology. All authors have read and agreed to the published version of the manuscript.

Funding: China Postdoctoral Science Foundation (2019M660471); Fundamental Research Funds for the Central Universities (FRF-TP-19-061A1).

Conflicts of Interest: The authors declare no conflict of interest.

\section{References}

1. Down, S.; Warren, L. Constructing narratives of enterprise: Clichés and entrepreneurial self-identity. Int. J. Entrep. Behav. Res. 2008, 14, 4-23. [CrossRef]

2. Murnieks, C.Y.; Mosakowski, E. Who am I? Looking inside the 'entrepreneurial identity'. Front. Entrep. Res. 2007, 27, 1-14.

3. Shepherd, D.A.; Haynie, J.M. Family business, identity Conflict, and an Expedited Entrepreneurial Process: A Process of Resolving Identity Conflict. Entrep. Theory Pr. 2009, 33, 1245-1264. [CrossRef]

4. Navis, C.; Glynn, M.A. Legitimate distinctiveness and the entrepreneurial identity: Influence on investor judgments of new venture plausibility. Acad. Manag. Rev. 2011, 36, 479-499.

5. Clarke, J.; Holt, R. The Mature Entrepreneur: A Narrative Approach to Entrepreneurial Goals. J. Manag. Inq. 2009, 19, 69-83. [CrossRef]

6. Bradley, D.E.; Roberts, J.A. Self-Employment and Job Satisfaction: Investigating the Role of Self-Efficacy, Depression, and Seniority. J. Small Bus. Manag. 2004, 42, 37-58. [CrossRef]

7. Uy, M.A.; Maw-Der, F.; Zhaoli, S. Joint effects of prior start-up experience and coping strategies on entrepreneurs' psychological well-being. J. Bus. Ventur. 2013, 28, 583-597. [CrossRef]

8. Shane, S.; Nicolaou, N. Creative personality, opportunity recognition and the tendency to start businesses: A study of their genetic predispositions. J. Bus. Ventur. 2015, 30, 407-419. [CrossRef] 
9. Teoh, H.Y.; Foo, S.L. Moderating effects of tolerance for ambiguity and risktaking propensity on the role conflict-perceived performance relationship: Evidence from Singaporean entrepreneurs. J. Bus. Ventur. 1997, 12, 67-81. [CrossRef]

10. Kraus, S.; Burtscher, J.; Vallaster, C.; Angerer, M. Sustainable Entrepreneurship Orientation: A Reflection on Status-Quo Research on Factors Facilitating Responsible Managerial Practices. Sustainability 2018, 10, 444. [CrossRef]

11. Rodríguez-Sánchez, J.-L.; González-Torres, T.; Montero-Navarro, A.; Gallego-Losada, R. Investing Time and Resources for Work-Life Balance: The Effect on Talent Retention. Int. J. Environ. Res. Public Health 2020, 17, 1920. [CrossRef]

12. Rodríguez-Sánchez, J.-L.; Montero-Navarro, A.; Gallego-Losada, R. The Opportunity Presented by Technological Innovation to Attract Valuable Human Resources. Sustainability 2019, 11, 5785. [CrossRef]

13. Ashforth, B.E.; Mael, F. Social identity theory and the organization. Acad. Manag. Rev. 1989, 14, $20-39$. [CrossRef]

14. Oyserman, D.; Coon, H.M.; Kemmelmeier, M. Rethinking individualism and collectivism: Evaluation of theoretical assumptions and meta-analyses. Psychol. Bull. 2002, 128, 3-72. [CrossRef]

15. Fromkin, H.L.; Snyder, C.R. The Search for Uniqueness and Valuation of Scarcity. In Social Exchange; Springer: Boston, MA, USA, 1980; pp. 57-75.

16. Glynn, M.A. Institutions and identity theory. In Handbook of Institutional Theory; Greenwood, R., Oliver, C., Suddaby, R., Sahlin-Andersson, K., Eds.; Sage: Addison, TX, USA, 2008.

17. Alvesson, M.; Ashcraft, K.L.; Thomas, R. Identity Matters: Reflections on the Construction of Identity Scholarship in Organization Studies. Organization 2008, 15, 5-28. [CrossRef]

18. Wieland, S.M. Ideal Selves as Resources for the Situated Practice of Identity. Manag. Commun. Q. 2010, 24, 503-528. [CrossRef]

19. Farmer, S.M.; Yao, X.; Kung-Mcintyre, K. The Behavioral Impact of Entrepreneur Identity Aspiration and Prior Entrepreneurial Experience. Entrep. Theory Pr. 2009, 35, 245-273. [CrossRef]

20. Gill, R.; Larson, G.S. Making the ideal (local) entrepreneur: Place and the regional development of high-tech entrepreneurial identity. Hum. Relat. 2013, 67, 519-542. [CrossRef]

21. Down, S.; Reveley, J. Generational Encounters and the Social Formation of Entrepreneurial Identity: 'Young Guns' and 'Old Farts'. Organization 2004, 11, 233-250. [CrossRef]

22. Donnellon, A.; Ollila, S.; Middleton, K.W. Constructing entrepreneurial identity in entrepreneurship education. Int. J. Manag. Educ. 2014, 12, 490-499. [CrossRef]

23. Ibarra, H. Provisional selves: Experimenting with image and identity in professional adaptation. Adm. Sci. Q. 1999, 44(4), 764-791. [CrossRef]

24. Montiel, C.H.; Alejandro, M.R.; Gerardo, H.A.; Marcela, P.C.Y. Relationship between creativity, personality and entrepreneurship: An exploratory study. Int. Bus. Res. 2015, 8, 59-71. [CrossRef]

25. Shalley, C.E.; Hitt, M.A.; Zhou, J. Introduction: Integrating creativity, innovation, and entrepreneurship to enhance the organization's capability to navigate in the new competitive landscape. In The Oxford Handbook of Creativity, Innovation, and Entrepreneurship; Oxford University Press: New York, NY, USA, 2015.

26. Shalley, C.E.; Zhou, J.; Oldham, G.R. The Effects of Personal and Contextual Characteristics on Creativity: Where Should We Go from Here? J. Manag. 2004, 30, 933-958. [CrossRef]

27. Anderson, N.; Potočnik, K.; Zhou, J. Innovation and Creativity in Organizations. J. Manag. 2014, 40, 1297-1333. [CrossRef]

28. Zhou, J.; Shalley, C.E. Deepening our understanding of creativity in the workplace: A review of different approaches to creativity research. In APA Handbook of Industrial and Organizational Psychology; American Psychological Association: Washington, DC, USA, 2011; pp. 275-302.

29. Eckhardt, J.; Shane, S.A. Opportunities and Entrepreneurship. J. Manag. 2003, 29, 333-349.

30. Brewer, M.B.; Gardner, W. Who is this "We"? Levels of collective identity and self representations. J. Personal. Soc. Psychol. 1996, 71, 83-93. [CrossRef]

31. Ibarra, H.; Barbulescu, R. Identity as narrative: Prevalence, effectiveness, and consequences of narrative identity work in macro work role transitions. Acad. Manag. Rev. 2010, 35, 135-154.

32. Zhou, H.-C.; Oldham, G.R. Enhancing Creative Performance: Effects of Expected Developmental Assessment Strategies and Creative Personality. J. Creat. Behav. 2001, 35, 151-167. [CrossRef] 
33. Shalley, C.E.; Oldham, G.R. Competition and Creative Performance: Effects of Competitor Presence and Visibility. Creat. Res. J. 1997, 10, 337-345. [CrossRef]

34. Selby, E.C.; Shaw, E.J.; Houtz, J.C. The Creative Personality. Gift. Child Q. 2005, 49, 300-314. [CrossRef]

35. Fillis, I.; Rentschler, R. The role of creativity in entrepreneurship. J. Enterprising Cult. 2010, 18, 49-81. [CrossRef]

36. Shane, S.; Venkataraman, S. The Promise of Entrepreneurship as a Field of Research. Acad. Manag. Rev. 2000, 25, 217-226. [CrossRef]

37. Markus, H.; Kunda, Z. Stability and malleability of the self-concept. J. Personal. Soc. Psychol. 1986, 51, 858-866. [CrossRef]

38. Duriez, B.; Soenens, B.; Beyers, W. Personality, identity styles, and religiosity: An integrative study among late adolescents in Flanders Belgium. J. Pers. 2004, 72, 877-910. [CrossRef]

39. Markus, H.; Wurf, E. The dynamic self-concept: A social psychological perspective. Annu. Rev. Psychol. 1987, 38, 299-337. [CrossRef]

40. Johnson, R.E.; Lord, R.G. Implicit effects of justice on self-identity. J. Appl. Psychol. 2010, 95, 681-695. [CrossRef]

41. Erikson, E.H. Identity: Youth and Crisis; Norton \& Compan: New York, NY, USA, 1968.

42. Hall, D.T.; Mirvis, P.H. The New Career Contract: Developing the Whole Person at Midlife and Beyond. J. Vocat. Behav. 1995, 47, 269-289. [CrossRef]

43. Pratt, M.G. The Good, the Bad, and the Ambivalent: Managing Identification among Amway Distributors. Adm. Sci. Q. 2000, 45, 456. [CrossRef]

44. Brewer, M.B. The Social Self: On Being the Same and Different at the Same Time. Pers. Soc. Psychol. Bull. 1991, 17, 475-482. [CrossRef]

45. Markus, H.R.; Kitayama, S. Culture and the self: Implications for cognition, emotion, and motivation. Psychol. Rev. 1991, 98, 224-253. [CrossRef]

46. Hisrich, R.D. Entrepreneurship/intrapreneurship. Am. Psychol. 1990, 45, 209-222. [CrossRef]

47. McMullen, J.S.; Shepherd, D.A. Entrepreneurial action and the role of uncertainty in the theory of the entrepreneur. Acad. Manag. Rev. 2006, 31, 132-152. [CrossRef]

48. Zhao, H.; Seibert, S.E.; Lumpkin, G. The Relationship of Personality to Entrepreneurial Intentions and Performance: A Meta-Analytic Review. J. Manag. 2009, 36, 381-404. [CrossRef]

49. Wright, M.; Hmieleski, K.; Siegel, D.S.; Ensley, M.D. The Role of Human Capital in Technological Entrepreneurship. Entrep. Theory Pr. 2007, 31, 791-806. [CrossRef]

50. Becker, G.S. Human Capital; Columbia University Press: New York, NY, USA, 1964.

51. Ployhart, R.E.; Moliterno, T.P. Emergence of the Human Capital Resource: A Multilevel Model. Acad. Manag. Rev. 2011, 36, 127-150. [CrossRef]

52. Unger, J.M.; Rauch, A.; Frese, M.; Rosenbusch, N. Human capital and entrepreneurial success: A meta-analytical review. J. Bus. Ventur. 2011, 26, 341-358. [CrossRef]

53. Marquis, C.; Tilcsik, A. Imprinting: Toward a multilevel theory. Acad. Manag. Ann. 2013, 7, $195-245$. [CrossRef]

54. Gimeno, J.; Folta, T.B.; Cooper, A.C.; Woo, C.Y. Survival of the Fittest? Entrepreneurial Human Capital and the Persistence of Underperforming Firms. Adm. Sci. Q. 1997, 42, 750. [CrossRef]

55. Aquino, K.; Freeman, D.; Reed, A.; Lim, V.K.G.; Felps, W. Testing a social-cognitive model of moral behavior: The interactive influence of situations and moral identity centrality. J. Pers. Soc. Psychol. 2009, 97, 123-141. [CrossRef]

56. Cardon, M.; Wincent, J.; Singh, J.; Drnovsek, M. The nature and experience of entrepreneurial passion. Acad. Manag. Rev. 2009, 34, 511-532. [CrossRef]

57. Hoang, H.; Gimeno, J. Becoming a founder: How founder role identity affects entrepreneurial transitions and persistence in founding. J. Bus. Ventur. 2010, 25, 41-53. [CrossRef]

58. Sarasvathy, S.; Venkataraman, S. Made, as well as Found: Researching Entrepreneurship as a Science of the Artificial; Yale University Press: New Haven, CT, USA, 2009.

59. Perry-Smith, J.E.; Mannucci, P.V. From Creativity to Innovation: The Social Network Drivers of the Four Phases of the Idea Journey. Acad. Manag. Rev. 2017, 42, 53-79. [CrossRef]

60. Bandura, A. Social Cognitive Theory: An Agentic Perspective. Annu. Rev. Psychol. 2001, 52, 1-26. [CrossRef] [PubMed] 
61. Gosling, S.D.; Rentfrow, P.J.; Swann, W.B.; Swann, W.B., Jr. A very brief measure of the Big-Five personality domains. J. Res. Pers. 2003, 37, 504-528. [CrossRef]

62. Aquino, K.; Americus, R., II. The self-importance of moral identity. J. Personal. Soc. Psychol. 2002, 83, 1423-1440. [CrossRef]

63. Anokhin, S.; Schulze, W.S. Entrepreneurship, innovation, and corruption. J. Bus. Ventur. 2009, 24, 465-476. [CrossRef]

64. DeMartino, R.; Barbato, R. Differences between women and men MBA entrepreneurs: Exploring family flexibility and wealth creation as career motivators. J. Bus. Ventur. 2003, 18, 815-832. [CrossRef]

65. Chatterjee, S.; Price, B. Regression Analysis by Example, 2nd ed.; John Wiley \& Sons: New York, NY, USA, 1991.

66. Muthén, L.K.; Muthén, B.O. Mplus User's Guide, 7nd ed.; Muthén \& Muthén: Los Angeles, CA, USA, 1998-2012.

67. Zhang, Z.; Zyphur, M.; Narayanan, J.; Arvey, R.D.; Chaturvedi, S.; Avolio, B.J.; Lichtenstein, P.; Larsson, G. The genetic basis of entrepreneurship: Effects of gender and personality. Organ. Behav. Hum. Decis. Process. 2009, 110, 93-107. [CrossRef]

68. Podsakoff, P.M.; Mackenzie, S.B.; Lee, J.Y.; Podsakoff, N.P. Common method biases in behavioral research: A critical review of the literature and recommended remedies. J. Appl. Psychol. 2003, 88, 879-903. [CrossRef]

69. Hofstede, G. Cultural Consequences: International Differences in Work-Related Values; Sage: Beverly Hills, CA, USA, 1980.

(C) 2020 by the authors. Licensee MDPI, Basel, Switzerland. This article is an open access article distributed under the terms and conditions of the Creative Commons Attribution (CC BY) license (http://creativecommons.org/licenses/by/4.0/). 